\title{
LARGE-SIZED DIGITAL BILLBOARDS HAZARD
}

\author{
K. DOMKE ${ }^{1}$, K. WANDACHOWICZ ${ }^{1}$, M. ZALESIŃSKA ${ }^{1}$, S. MROCZKOWSKA ${ }^{1}$ \& P. SKRZYPCZAK ${ }^{2}$ \\ ${ }^{1}$ Poznan University of Technology, Institute of Electrical Engineering and Electronics, Poland. \\ ${ }^{2}$ City Road Administration Poznań, Poland.
}

\begin{abstract}
Various kinds of media are used for outdoor advertising purposes. One such medium comprises large electronic billboards with light-emitting diodes (LED) as the source of light. Such novel advertising devices' photometric parameters are different than in the media used so far and consequently impact road traffic participants in a different manner. Digital billboards with electroluminescent diodes are large, have high luminance, and display dynamically changing images. Billboards located near streets are a potential threat to traffic safety. The paper presents requirements for such billboards, the results and analysis of measurements of selected billboards located in Poznań, Poland, as well as conclusions and recommendations for large-sized billboards with LED located in the vicinity of roads and intersections.

Keywords: Digital billboards, light engineering, road safety.
\end{abstract}

\section{INTRODUCTION}

Large-sized billboards have been in operation for a long time, dating back to 1900 in United States. At first, these were simply large billboards covered with paper advertisements. To provide better visibility, also at night, external lighting sources projecting light onto the billboards have been used, and when the advertisement's carrier is replaced with fabric or PVC, backlight has been used. These are the most common billboards seen and operated in cities and highly populated areas. The employed lighting sources include lamps with fluorescent, halogen, metal halide, and LED light sources. The surface (up to $5 \mathrm{~m}^{2}$ ) of such a billboard illuminates transmitted or reflected light with relatively low illuminance $(0.5-5 \mathrm{~lx})$.

Similarly to many developed countries all over the world, large-sized (12-72 $\left.\mathrm{m}^{2}\right)$ [1] electronically controlled billboards with LED diodes as the main source of light have appeared in Polish cities, towns, and other populated areas. Compared to traditionally illuminated billboards, these feature much higher brightness values (light intensity or luminance).

The dramatic increase of the number of such billboards (55 in 2009, 213 in 2010, in Poland) [1] may pose direct danger to road traffic participants, not to mention the unappealing visual disorder due to overcrowding of such advertising devices.

One of the factors increasing such risk is improperly operated, excessively bright electronic billboards (Fig. 3).

With the development of the technology of LED, large-sized billboards with electroluminescent diodes have come to the towns of Poland. These billboards are usually large, have high luminance, and show dynamically changing images. Car, bus, and rail vehicle drivers complain that glaring billboards located in their field of vision are uncomfortable to look at and interfere with normal driving tasks, especially in the evening and at night. Billboards located near streets are a potential threat to traffic safety.

The use of a high quantity of LEDs and an electronic control system makes such devices similar to TV screens, which gives the use novel, previously unavailable functionalities, with photometric parameters unlike the previous ones. Given their large area, such billboards feature very high brightness - much higher than traditional billboards. In addition, the presented content may feature brightness of various levels and dynamically changing images (video, animation). At nighttime and 


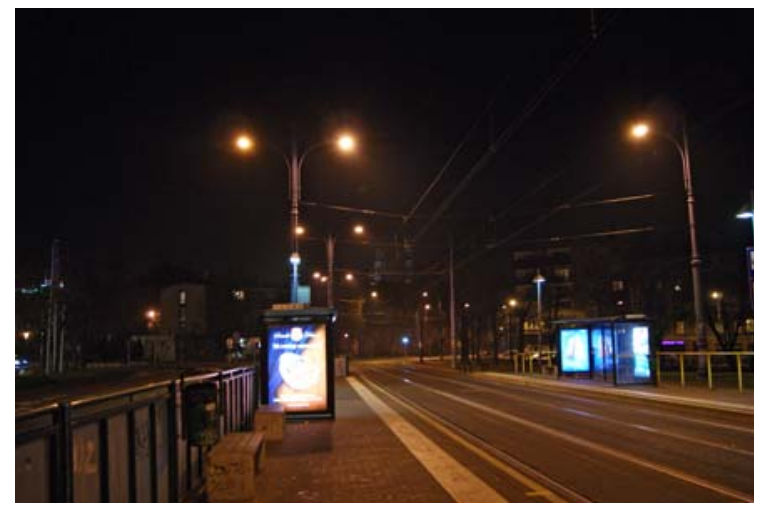

Figure 1: Small billboards (cityboards) on tram stop.

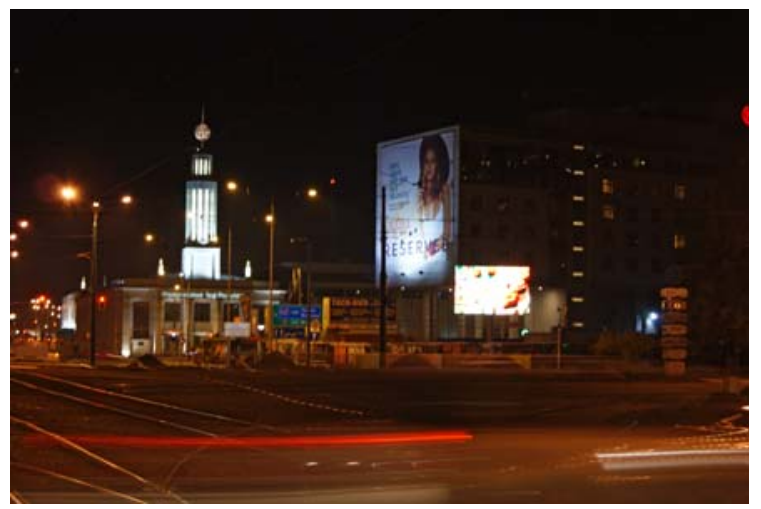

Figure 2: Large-sized digital billboards on city roundabout.

in poor atmospheric conditions during the day (e.g. cloudy sky, fog, rain) such billboards may uncomfortably impair the drivers' vision and hinder their ability to normally drive cars. A great majority of them are a potential source of glare and distraction among the drivers. By displaying content that resembles road traffics signs, such billboards often mislead the drivers.

Aiming to reach as many potential content viewers as possible, billboard owners install them mostly in places with intensive vehicle and pedestrian traffic, such as main traffic routes, intersections, traffic circles, and close to heavily used roads and pedestrian crossings, thus putting traffic participants in danger. The lack of explicit legal regulations for operating such devices makes the situation only more evident.

The problem of negative impact of large-sized billboards on the drives has been acknowledged and partially examined, and authorities at various levels (local, state, sometimes even national) have been trying to specify permissible operating conditions for such billboards.

Legal regulations applicable in other countries are far from coherent: from complete prohibition of use across the entire country (Spain), through country-specific (Holland, South Africa, Brazil) or local partial restrictions on selected parameters in force in specific states (Queensland, Victoria, New South Wales in Australia, New York, Virginia in USA) through specific cities (San Antonio, Oakdale in USA) to no legal regulations whatsoever (numerous countries in Asia and Middle East). 


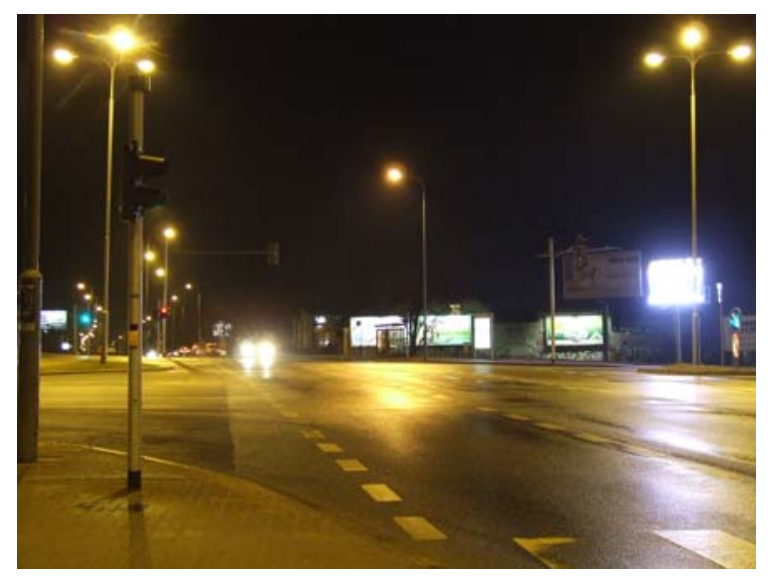

Figure 3: Billboards placed too low and with high brightness.

The following are examples of requirements that apply to such billboards, accepted by local selfgovernments, states, and government bodies in countries that have already acknowledged the problem of outdoor billboards. Also, results of measurements of photometric and geometric parameters of selected billboards located in Poznań, Poland, have been presented, and recommendations for the operation of large-sized billboards with LEDs have been formulated.

\section{EXAMINATION OF BILLBOARDS AND THEIR IMPACT ON DRIVERS}

All over the world numerous and continued research projects have been completed, aiming at establishing the impact of large-sized LED billboards on road traffic safety and formulating requirements and recommendations regulating the principles of installation and operation of such devices. The great majority of research projects were devoted to the topic of distracting the drivers due to the manner and type of the displayed advertising content [2-9]. Among others, the researchers examined the impact of animated images and video, information presented in advertisements (website addresses, text message details, phone numbers, etc.), the legibility of advertisements, the element of novelty achieved by displaying the advertisements in specific sequences, and the impact of the effect of attracting the drivers' vision by very bright surfaces in their field of vision on their distraction. Only a few projects actually focused on the billboards' photometric properties (luminance). Rather, the literature makes an attempt at adapting the results of examinations on traditional advertisements to LED billboards [10]. Also, attempts are made to adapt the results of research on light that distracts residents in relation to the evaluation of photometric properties of electronic billboards [11].

In 2010, the Poznan University of Technology conducted the first examination of the basic photometric properties of electronic billboards in Poland. Measurements of properties of LED billboards were taken for a selected group of advertisements located in Poznań. The most significant factors derived from the analyzed billboards impacting the drivers' vision conditions have been analyzed and isolated. A proprietary measurement procedure has been created. The description of the research, the measurement procedure, and the results are presented in [12,13]. The results permitted the evaluation of photometric parameters of typical billboards located in Poznan and confirmed the necessity to introduce specific requirements and legal regulations that would render the installation and operation of such objects impossible. 


\section{CURRENT LEGAL SITUATION IN POLAND}

The Polish lighting standards related to the lighting of work places located outdoors [14] and road lighting [15] do not specify requirements for large-sized billboards with LEDs as objects impacting road traffic safety. The standard [14] consists of requirements on the limitation of interfering lighting and only address the reduction of inconvenience for people, animals, and plants. The stipulations of the standard fail to address requirements related to driving (drivers of vehicles present in the road). Only maximum luminance and luminous intensity values of signs, including billboards emitting light (or illuminated ones) are specified. Unfortunately, the location of the billboard toward the observer, its angular diameter, distance from the main direction of observation, and dynamic change of luminance (brightness) related to displayed images are not taken into account.

The Polish standard's [15] requirements related to glare limitation only apply to situations where small-sized light sources (luminaires) are present in the road. The evaluation of glare is carried out on the basis of the increase of the threshold value (TI). Consequently, such requirements may not be used when evaluating glare caused by large-sized billboards with LEDs.

The currently valid ordinance of the Polish Ministry of Infrastructure [16] (point 79 applying to Art. 293 Para. (6) provides requirements for lighting devices, including billboards located outdoors or in the vicinity of buildings that may be inconvenient for pedestrians and drivers. Still, these requirements are not accurate and are no grounds to evaluate the level of inconvenience caused by billboards, especially for drivers. The ordinance specifies requirements on the illuminance of white light (5 lx) and color light ( $3 \mathrm{~lx})$, but there is no description of the method of carrying out measurements in relation to both the location and external factors (impact of lighting in the road installation). Although the ordinance talks about drivers, these requirements seem to be applicable only to those lights causing inconvenience to residents.

The Polish Outdoor Advertising Chamber, whose members are mainly owners of such billboards, has issued recommendations on digital advertisements that only comprise generic statements on the obligation to operate billboards which are 'not arduous for residents in the area of their effect and not arduous to road traffic participants' and to ensure that there is a distance of at least $50 \mathrm{~m}$ between intersections and billboards displaying images that change more frequently than one in $5 \mathrm{~s}$. [17] Unfortunately, these recommendations are not obeyed in many cases.

\section{REVIEW OF REQUIREMENTS APPLICABLE TO LARGE-SIZED BILLBOARD WITH LEDS}

Numerous countries carry out research on the impact of roadside billboards on reduced concentration of drivers. To a large extent, the research applies to traditional advertisement media, but there are in fact several papers on electronic advertisement [18]. Generally speaking, the results of all research projects indicate that billboards distract drivers. Several countries have implemented guidelines for issuing permits for installation of roadside billboards on the basis of results of such research projects, which were carried out mostly at the request of governmental bodies or road authorities.

In general, the current requirements and limitations applying to digital billboards fall into three groups:

- Limitations of photometric parameters and location,

- Recommendations on graphical effects,

- Recommendations on the advertisements' content.

Among the recommended limitations in the first group the one which seem most important are related to photometric parameters (brightness, luminance, and illuminance). Brightness is subjective, 
hence cannot be objectively measured. Electronic billboards seem less bright during the day than at night. Billboards seen at night, in city centers, seem less bright than the same billboards observed in dark, unoccupied surroundings. Electronic billboards made from electroluminescent diodes are original sources emitting light by themselves, hence luminance should be used to describe their properties.

Generally, there is no need to limit the luminance of billboards during the day, but there is no doubt such limits should be imposed for billboards at night. The so-called moth effect, described as unintentional directing of one's eyesight to the brightest objects in the field of view. Consequently, the brighter the surface of the billboard, the higher the danger it poses with regard to distracting the driver and leading their eyesight off the road [3].

The luminance of billboard surfaces may not be specified explicitly, as brightness (a subjective sensation) depends on the area of the billboard and the luminance of the surroundings. In general, all literature sources specify the billboard's luminance as the only value affecting the billboard's brightness. Only Outdoor Advertising Association of America (OAAA), an association of manufacturers of advertising media, specifies requirements for illuminance $[19,10]$.

A document titled 'Technical Memorandum: Evaluation of Billboard Sign Luminances' was drawn up in 2008 by the Lighting Research Center, Rensselaer Polytechnic Institute at the request of the New York State Department of Transportation. The memorandum describes three stages of research: a review of recommendations for luminance calculation (on the basis of the paper by IESNA), measurements of luminance of existing billboards, and a computer simulation of an electronic billboard. According to IESNA recommendations, the illuminance in the surface of an electronic billboard should be $1000 \mathrm{~lx}$ for bright surroundings and $500 \mathrm{~lx}$ for dark surroundings. Assuming that the billboard surface coefficient of reflection of the light stream is 0.8 , its corresponds to luminance is $250 \mathrm{~cd} / \mathrm{m}^{2}$ and $130 \mathrm{~cd} / \mathrm{m}^{2}$. The authors confirm that these assumptions are followed by billboard manufacturers. The authors have also measured existing billboards: six backlit billboards and four electronic billboards. The memorandum authors' own research lead them to a conclusion that the luminance of a backlit billboard should not exceed $280 \mathrm{~cd} / \mathrm{m}^{2}$ at night.

A document [20] listing requirements for roadside billboards has been developed at the request of the Traffic Engineering and Road Safety section of the Queensland (Australia) Government's Department of Main Roads. The document's characteristic feature is the listing of several definitions. For example, roadside billboards are divided into four categories depending on their size and placement in relation to the road. Attachment D discusses the billboards' brightness and quotes a paper [21] on backlit billboards. The paper claims that 'the brightness of backlit roadside billboards should be limited under any conditions'. The authors emphasize the difference between the concepts of brightness and luminance. Luminance is used for assessing the properties of a billboard as a device for displaying images. Luminance may be different in the billboard's surface (luminance distribution) and depending on the angle of observation. The highest luminance occurs when observing the billboard from straight ahead and is reduced as the angle of observation increases. Brightness is a subjective visual sensation, whose intensity depends on the luminance of the billboard's surface (luminance distribution), the size of the billboard, the contrast (in relation to background luminance), the observer's position, and the observer's adaptation. The document presents the maximum permissible, average luminance of the billboard's surface for three areas (Table 1).

The reduction of the billboard's surface luminance is not required at night only but also in certain situations during the day. In case of a fog, bright billboard surfaces may hamper the drivers' vision. To ensure luminance is reduced during fog, it may not be enough to equip billboards with photodetection devices reducing their luminance at night. Other dedicated requirements for such situations may have to be implemented. 
Table 1: Permissible luminance values of billboards' surfaces according to [22].

\begin{tabular}{llc}
\hline Area number & \multicolumn{1}{c}{ Description } & Permissible luminance value \\
\hline 1 & $\begin{array}{l}\text { Area with high level of lighting, not } \\
\text { caused by road lighting system, e.g. } \\
\text { city centers. }\end{array}$ & $500 \mathrm{~cd} / \mathrm{m}^{2}$ \\
& $\begin{array}{l}\text { Area with average level of lighting, not } \\
\text { caused by road lighting system, e.g. } \\
\text { suburban industrial areas, filling sta- } \\
\text { tions, parking lots, etc. }\end{array}$ & $350 \mathrm{~cd} / \mathrm{m}^{2}$ \\
& $\begin{array}{l}\text { Area with low level of lighting, not } \\
\text { caused by road lighting system, e.g. } \\
\text { rural areas, residential areas. }\end{array}$ & $300 \mathrm{~cd} / \mathrm{m}^{2}$ \\
\hline
\end{tabular}

Table 2: Minimum distances of building structures from the external edge of the roadway for various classes of roads [25].

\begin{tabular}{llcc}
\hline No. & \multicolumn{1}{c}{ Road class } & Built-up area & Outside built-up area \\
\hline 1 & National road & $10 \mathrm{~m}$ & $25 \mathrm{~m}$ \\
2 & Regional road & $8 \mathrm{~m}$ & $20 \mathrm{~m}$ \\
3 & District road & $8 \mathrm{~m}$ & $20 \mathrm{~m}$ \\
4 & Local road & $6 \mathrm{~m}$ & $15 \mathrm{~m}$ \\
\hline
\end{tabular}

Another important factor is the billboard's location: authors of numerous publications agree that electronic billboards distract drivers, thus becoming a potential source of danger for the safety of road traffic participants. Such billboards should not be located in the direct vicinity of intersections, road junctions, and in places where drivers are required to pay special attention (e.g. near pedestrian crossings). It is often suggested to only place billboards perpendicularly to the axis of the road [23,24]. Minimum distances between a billboard and an intersection within towns are specified to be between about $10 \mathrm{~m}$ up and about $50 \mathrm{~m}$. In Poland, the recommended minimum distance from the billboard's side (its closest edge) to the edge of the road should be, for every road class, according to the public road law [25]. Table 2 presents minimum distances of building structures from the external edge of the roadway for various classes of roads.

The billboard's surface should be positioned to have the least negative impact on the drivers' vision process. Some authors suggest, that the billboard's surface should be situated within angles $90^{\circ} \div 180^{\circ}$ in relation to the edge of the roadway (in relation to the edge of the roadway) and illumination directions should be opposite to sites with elevated collision (accident) risk, for example, opposite to intersections or traffic circles. Figure 4 shows the billboard's permitted position and illumination direction [26].

In addition, a large-sized billboard should be positioned so as not to block the view of equipment critical for road traffic safety, exit from a minor road or a parking (it is sometimes observed - see Figs. 5 and 6), or a fire escape route or its designation signs [27,24]. 


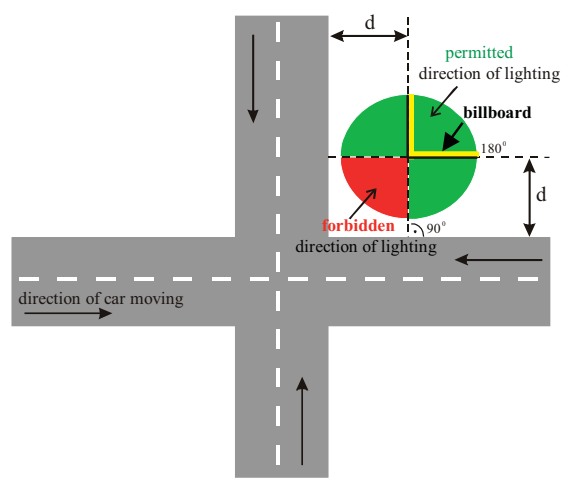

Figure 4: Permitted and forbidden position for billboard at the intersection [26].

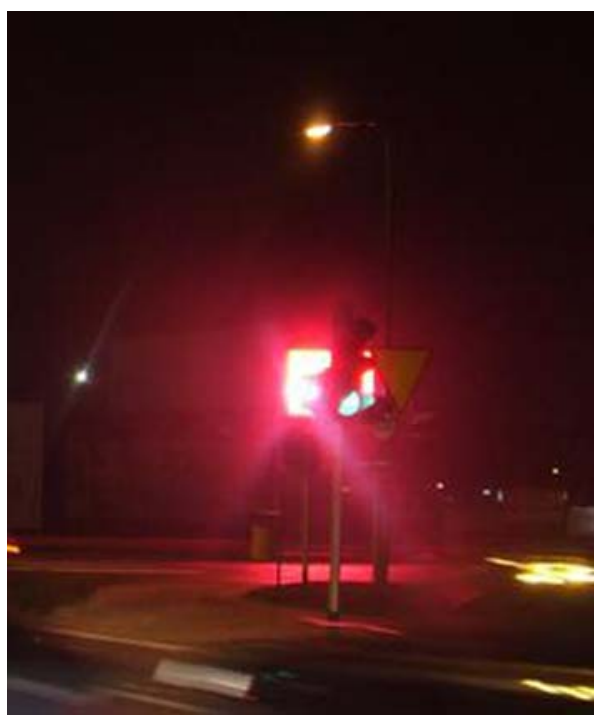

Figure 5: Wrong location - billboard as the background for the traffic sign.

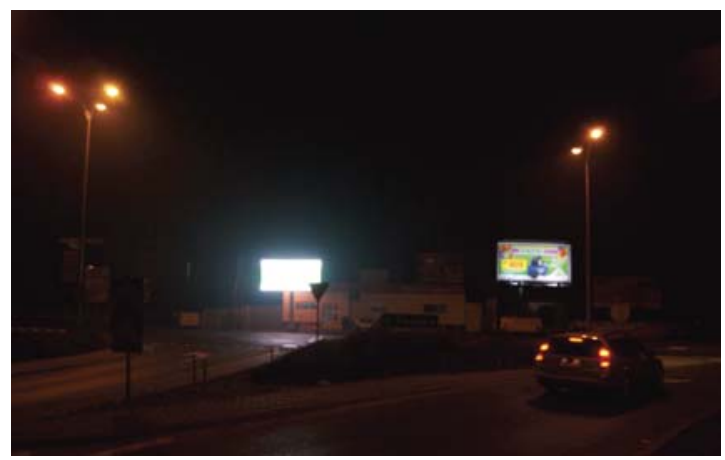

Figure 6: Wrong location - billboard at exit from a minor road. 
The second group of limitations includes the ones regulating the manner of use of the displayed image's graphical elements.

Moving images (video clips) are forbidden. The issue of displaying moving images is well covered by world literature [25,6,28]. Displaying moving images (animation, video) is explicitly forbidden. Electronic billboards may only display permanent images.

Also minimum billboard display time is limited. This issue raises disputes between billboard owners and road traffic safety specialists. A billboard owners' agenda is to present as many advertisements in a given time unit as possible, provided the display time is long enough for the advertisements to be read and comprehended. There is no information on research projects aiming at evaluation of the impact of operation of billboards on distracting drivers. Different sources quote different times, but the data is not substantiated with empirical research. OAAA, an association of manufacturers of advertising media, quotes a time of $4 \mathrm{~s}$ [29]. The Federal Highway Administration (FHWA) operating in United States recommends a time of $8 \mathrm{~s}$ [28]. Recommendations implemented in 41 states in North America specify a time from 4 to $10 \mathrm{~s}$ [28]. The necessity to specify the minimum time of displaying advertisements comes as a consequence of the so-called Zeigarnik effect occurring in case of sequentially appearing advertising messages, provoking the observer to observe the remaining part of the message, leading to a much worse concentration of the driver. This is to be prevented by a requirement saying that the observer (driver) is not supposed to observe changing images in the billboard but rather is supposed to see the same still advertisement in the device [30]. The minimal time $t$ of displaying an advert should therefore be connected with the distance $d$ at which the advertisement is being observed and the speed limit $v$ introduced for the road in the vicinity of which the billboard is located. The analyzed literature suggests the following recommendation is applied in eqn. (1):

$$
t=\frac{d}{v}
$$

where $t$ - minimum advert display time [s], $d$-distance from the billboard [m], $v$ - speed limit [m/s].

Visual effects and interval between consecutive images. Generally, all available publications unanimously claim that there should be no delay between the changing images of consecutive advertisements. Also, no visual effects should be used between the changing images. Images must not be dimmed, brightened, overlapping, and animated [28].

Also, amount of displayed information is limited. The longer the time the driver is forced to read an advertisement, the higher the threat to traffic safety. Research has proven [6] that drivers start reading advertising texts located at a distance of $250 \mathrm{~m}$ if the letters of the text are $45 \mathrm{~cm}$ high. Reading speed is assumed at one word per second, which gives a maximum number of eight words at the speed of $90 \mathrm{~km} / \mathrm{h}$, seven words at $100 \mathrm{~km} / \mathrm{h}$, and six words at $115 \mathrm{~km} / \mathrm{h}$. The number of words should be lower in unfavorable conditions (lower letters, reduced contrast). No specific recommendations have been specified, with this regard. Still, it is known that the amount of information in the billboard should depend on the speed limit in the area and the distance to the billboard.

Sequential messages (text that appears on consecutively displayed advertising messages) are forbidden [20].

Images whose shape or color resemble road traffic signs [20,24] or officially used emergency signals or traffic light signals [31] are forbidden. Unfortunately, such billboards are still in use (Fig. 5). 

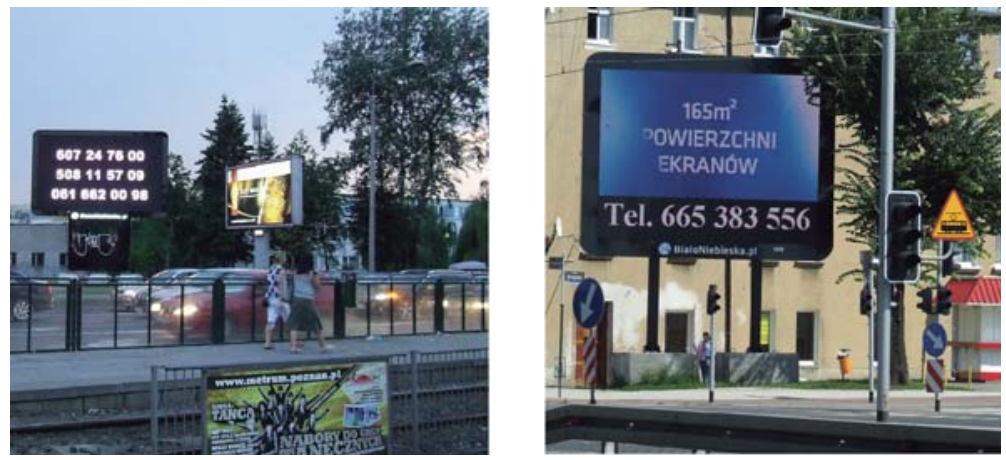

Figure 7: Billboards with information to memorize: addresses, phone numbers.

The third group of limitations specifies the type of displayed information. Billboards should not display website addresses, phone numbers, and text message details. This kind of content requires special attention of the driver to memorize it (write it down) consequently distracting the driver (Fig. 7) [23].

It is also forbidden to display controversial content (sex, violence, religious symbols) [23].

Permits. Authorities issuing permits should be able to analyze annually the impact of electronic billboards on road traffic safety in a given location. Also, the billboard's properties may alter when its elements or software are changed. Ultimately, new requirements may be accepted (on the basis of newly conducted research), which may lead to the change of, for example, billboards' luminances. It is recommended [28] to follow the method used by Oakdale, Minnesota, authorities [32]. The billboard's investor (owner, operator) obtains a 1-year permit to operate the billboard and is required to renew it annually.

\section{RESEARCH OF LARGE-SIZED BILLBOARDS WITH LEDS IN POZNAŃ, POLAND}

In the summer of 2010, over 30 large-sized billboards with LEDs have been located in the administrative territory of the big polish town of Poznan. These billboards are usually large, very bright, and show dynamically changing images whose brightness varies greatly (videos, animated images), especially at night. Figure 8 shows an example of a very bright billboard with LEDs.

Billboards with LEDs are usually installed in places where the daily traffic is very high (city centers, high streets, intersections, roundabouts), and thus significantly impact the drivers' vision conditions, leading to reduced concentration and even glare. Thus, they are a potential threat to road traffic safety. Figure 9 shows an example of location of a billboard near an intersection.

Measurements of properties of large-sized billboards with LEDs have been carried out for 18 billboards located in Poznań. The measurements have been carried out after sunset, as billboards impact drivers' vision the most at night. All examined billboards have been located in the drivers' fields of view, $1.5 \mathrm{~m}$ to $13 \mathrm{~m}$ above ground. All billboards were large and showed dynamically changing images, except for a single billboard showing still images. The surface of the largest billboard was approximately $30 \mathrm{~m}^{2}$, and approximately $5 \mathrm{~m}^{2}$ for the smallest one. Table 3 shows the highest and lowest values of the measured geometric parameters and average values for all billboards.

A site plan showing the location of the measurement point, main observation directions, and the location of the billboard in relation to the road has been drawn up during the measurements. The main directions of observation of the surface of the billboard were selected following the analysis 

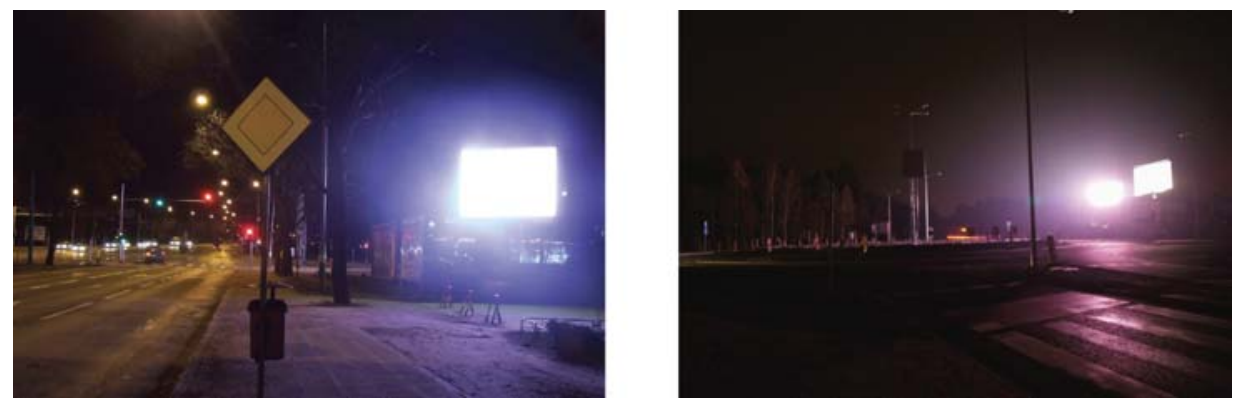

Figure 8: View of a very bright billboards at night.
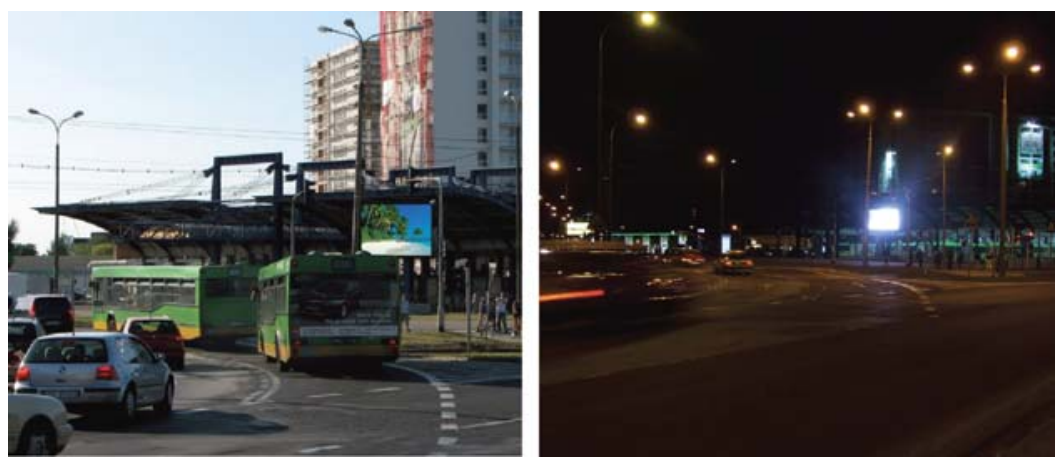

Figure 9: A billboard located in a place where daily traffic is high (as seen during the day and at night) [26].

Table 3: Highest and lowest values of the measured geometric parameters and average values for examined billboards.

\begin{tabular}{lccc}
\hline $\begin{array}{l}\text { Billboard's geometric } \\
\text { parameter }\end{array}$ & $\begin{array}{c}\text { Average value for } \\
\text { all billboards }\end{array}$ & $\begin{array}{c}\text { Highest of } \\
\text { measured values }\end{array}$ & $\begin{array}{c}\text { Lowest of } \\
\text { measured values }\end{array}$ \\
\hline height $[\mathrm{m}]$ & 3.1 & 4.8 & 1.2 \\
width $[\mathrm{m}]$ & 4.9 & 6.3 & 2.9 \\
surface $\left[\mathrm{m}^{2}\right]$ & 15.2 & 30.1 & 5.4 \\
\hline
\end{tabular}

of the location of the billboard in relation to the layout of the street and the traffic system (one-way streets, no turn or turn only signs). The location of measurement points was based on the assumed division of angles, for which the billboard's luminance was measured and possibilities of taking practical measurements were assessed. Figure 10 shows examples of site plans of two measurement points.

The measurement of photometric parameters included the measurement of the luminance of the billboard's central point, the luminance of the surface of the road as the adaptive surface for road users and the luminance of the billboard's background. The luminance of the billboard's central point was measured in plane perpendicular to the surface of the billboard's measurement point. 

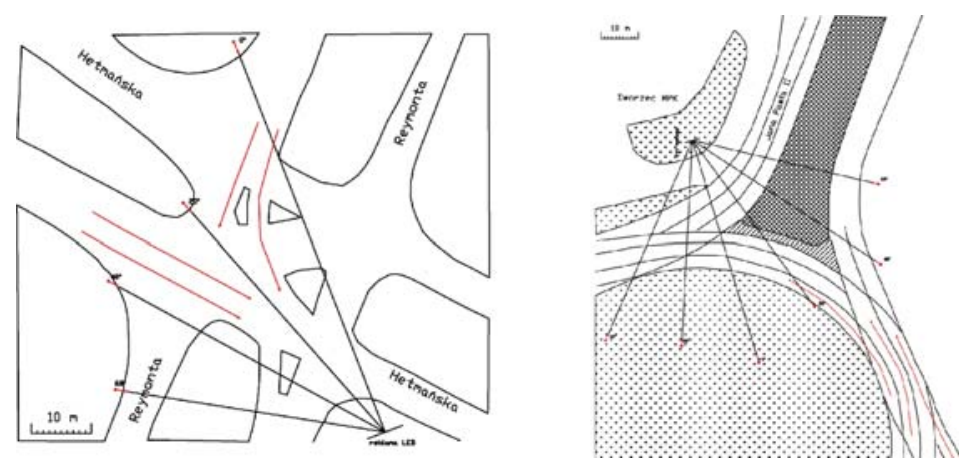

Figure 10: Street layout indicating the examined billboard and locations of measurement points for angles $0^{\circ}, 20^{\circ}, 40^{\circ}, 60^{\circ}$ and main directions (marked with arrows in traffic lanes) [26].

Table 4: List of measured luminance values.

\begin{tabular}{lccc}
\hline Luminance $\left[\mathrm{cd} / \mathrm{m}^{2}\right]$ & $\begin{array}{c}\text { Average value for } \\
\text { all billboards }\end{array}$ & $\begin{array}{c}\text { Highest of } \\
\text { measured values }\end{array}$ & $\begin{array}{c}\text { Lowest of } \\
\text { measured values }\end{array}$ \\
\hline Maximum for billboard's central point & 1983 & 7953 & 377 \\
Billboard surroundings & 9.3 & 108 & 0.9 \\
Horizon & 1.8 & 6.5 & 0.2 \\
Road surface & 3.1 & 4.6 & 1.1 \\
\hline
\end{tabular}

The billboard's maximum and minimum luminance in this point was measured. The change of luminance in the billboard's central point depending on four different angles of observation in relation to the plane perpendicular to the surface of the billboard was measured. The road surface average luminance was measured for the lane of traffic moving toward the billboard. The billboard's background luminance was measured for surfaces located in its closest vicinity and for the horizon in the back of the observed billboard.

Table 4 presents the summary of luminance measurements, and a selected distribution of luminance in the billboard's surroundings is shown in Fig. 11.

\section{ANALYSIS OF OBTAINED RESULTS}

The measurements of properties of large-sized billboards with LEDs confirmed the existence of high values of luminance of billboard surfaces at low values of luminance of the vicinity of the billboards. If a value of $500 \mathrm{~cd} / \mathrm{m}^{2}$ suggested in [12,21] and presented in Table 1 is assumed as a criterion of evaluation of permissible values of luminance for high illuminance surfaces, then only 2 out of the examined 18 billboards meet this requirement. The two billboards had maximum luminance of 377 $\mathrm{cd} / \mathrm{m}^{2}$ and $388 \mathrm{~cd} / \mathrm{m}^{2}$. The remaining billboards luminance was from $554 \mathrm{~cd} / \mathrm{m}^{2}$ to $814 \mathrm{~cd} / \mathrm{m}^{2}$ (6 billboards) and over $1000 \mathrm{~cd} / \mathrm{m}^{2}$ - from $1051 \mathrm{~cd} / \mathrm{m}^{2}$ to $7953 \mathrm{~cd} / \mathrm{m}^{2}$ (10 billboards). The average luminance of the surface of all examined billboards was $1983 \mathrm{~cd} / \mathrm{m}^{2}$, given the average background luminance below $10 \mathrm{~cd} / \mathrm{m}^{2}$ and average road surface luminance, namely adaptive luminance, of approximately $3 \mathrm{~cd} / \mathrm{m}^{2}$. Almost all examined billboards featured highly variable parameters and high luminance contrasts of the displayed images. The highest value of luminance contrast, defined as the relation of the luminance of the object to the luminance of the background, was over 4000 . 


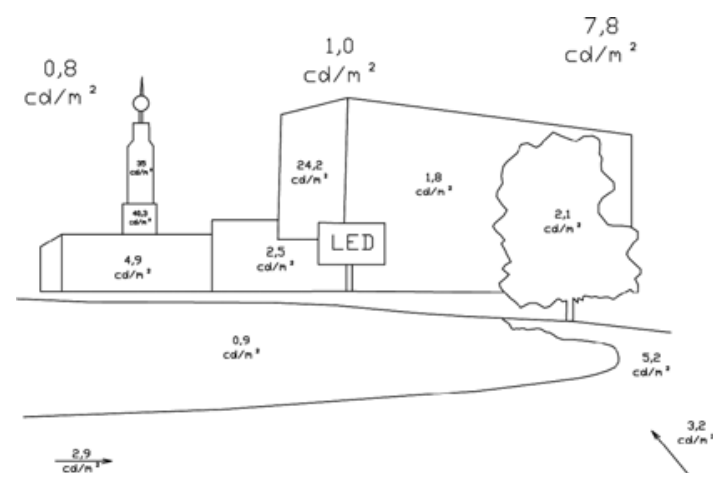

Figure 11: Distribution of luminance $\left(\mathrm{cd} / \mathrm{m}^{2}\right)$ in the surroundings of the billboard from Fig. 3 [26].
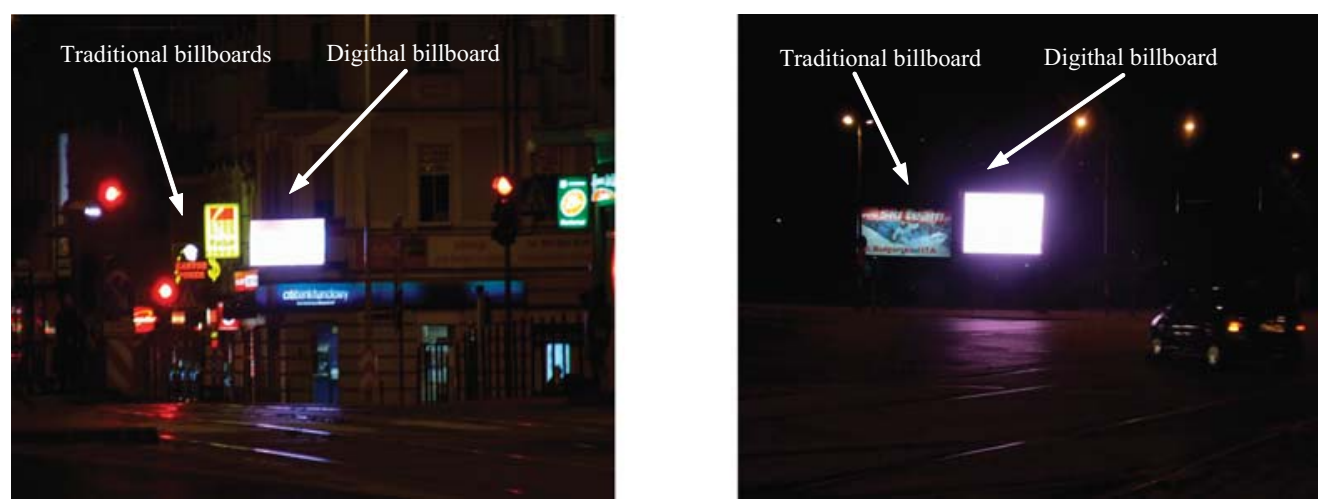

Figure 12: Billboards with too big luminance are illegible.

In such cases, the observed loss of the ability to read the displayed content of the advertising because of its too much brightness and too much contrast with the surroundings. Figure 12 illustrates this case.

The obtained results show it is necessary to impose limits for billboard luminance values at night.

\section{CONCLUSIONS}

The completed measurements and their analysis have shown the negative impact of large-sized billboards with LEDs on drivers' vision conditions, especially at night.

Factors resulting in negative impacts of such billboards may be divided into three categories:

- Photometric parameters of billboards (high luminance at low background value, high contrast of images) can dazzle drivers.

- Special character of images (dynamic changes, flashing, contents for memorization) disrupted the process of seeing the road.

- Inappropriate location (near intersections, roundabouts, road vicinity, at low heights, before road traffic signs).

On the basis of research results, experience, and the analysis of recommendations discussed in other papers, the authors suggest requirements and limits related to large-sized billboards: 
- Maximum luminance of billboard surface: at night $400 \mathrm{~cd} / \mathrm{m}^{2}$, during the day $5000 \mathrm{~cd} / \mathrm{m}^{2}$,

- Billboard location: $90^{\circ} \div 180^{\circ}$ in relation to road surface border, without emission of light toward locations with higher risk of road collisions, outside intersections.

- Unacceptable form of images: moving images, visual effects, interval between consecutive images, information for memorize (addresses, websites, emails, phone numbers, text message instructions).

- Minimum advertisement display time: $10 \mathrm{~s}$.

\section{REFERENCES}

[1] Informacja Izby Gospodarczej Reklamy Zewnetrznej w sprawie danych o wielkosci rynku reklamy out of home według stanu na dzien 31.12.2009 roku. (pol), (Information of the Outdoor Advertising Commercial Chamber on out of home advertising market size data as of December 31, 2009) Izba Gospodarcza Reklamy Zewnetrznej, http://www.igrz.com.pl/page7.html

[2] Crundall D., Van Loon, E. \& Underwood, G. Attraction and distraction of attention with roadside advertisements. Accident Analysis and Prevention, 38(4), pp. 671-677, 2006. doi: http://dx.doi.org/10.1016/j.aap.2005.12.012

[3] Green, M. Is the moth effect real? Accident Reconstruction, May/June, pp. 18-19, 2006.

[4] Theeuwes J., Kramer, A.F., Hahn, S. \& Irwin, D.E. "Our eyes do not always go where we want them to go: Capture of the eyes by new objects." Psychological Science, 9(5), pp. 370-385, 1998. doi: http://dx.doi.org/10.1111/1467-9280.00071

[5] Beijer, D.D. Driver distraction due to roadside advertising. University of Toronto, Department of Mechanical and Industrial Engineering, 2002.

[6] Dudek, C.L. Changeable Message Sign Displays During Non-Incident, Non-Roadwork Periods: A Synthesis of Highway Practice. NCHRP Synthesis 383. Washington, DC: Transportation Research Board, 2008.

[7] Manual on Uniform Traffic Control Devices. Washington, DC: U.S. Department of Transportation, Federal Highway Administration, 2003. Available at: http://mutcd/fhwa.dot.gov

[8] Road Safety Committee. Inquiry into Driver Distraction - Report of the Road Safety Committee on the Inquiry into Driver Distraction. Parliamentary Paper No. 209 Session 2003-2006. Victoria, Australia: Parliament of Victoria, 2006.

[9] Speirs, S., Winmill, A. \& Kazi, T. The Impact of Roadside Advertising on Driver Distraction: Final Report. Basingstoke, Hampshire, England: WSP Development and Transportation, 2008.

[10] Lewin, I. Digital Billboard Recommendations and Comparisons to Conventional Billboards. Lighting Sciences Inc.

[11] IESNA, Technical Memorandum on Light Trespass: Research, Results and Recommendations. IESNA TM-11-2000.

[12] Wandachowicz K., Zalesinska M., Domke K., Mroczkowska S., Skrzypczak P., Wielkopowierzchniowe reklamy z diodami swiecacymi a bezpieczenstwo ruchu drogowego. (pol), (Large size LED billboards and road traffic safety), Przeglad Elektrotechniczny, nr 4, ss. pp. 73-77, 2011.

[13] Wandachowicz K., Zalesinska M., Domke K., Mroczkowska S., Skrzypczak P., Digital billboards and road safety. (Chapter x) Light in Engineering, Architecture and the Environment. ed. K. Domke, C.A. Brebbia, WITPress, Southampton: Boston, pp. 119-132, 2011.

[14] Polish Standards, PN-EN 12464-2:2008 Swiatło i oswietlenie. Oswietlenie miejsc pracy. Czesc 2: Miejsca pracy na zewnatrz, (pol.).

[15] Polish Standards, PN-EN 13201-3:2007 Oswietlenie drog, (pol.).

[16] Rozporzadzenie Ministra Infrastruktury z dnia 12 marca 2009 zmieniajace rozporzadzenie w sprawie warunkow technicznych, jakim powinny odpowiadac budynki i ich usytuowanie. 
(pol.), (The Ordinance of the Minister of Infrastructure dated March 12, 2009, amending the ordinance of technical conditions to be met by buildings and their location).

[17] Zasady funkcjonowania nosnikow reklamy w przestrzeni publicznej. (pol.), (Principles of operation of advertising media in public space) Izba Gospodarcza Reklamy Zewnetrznej, http://www.igrz.com.pl/page19.html

[18] Lee, S.E., McElheny, M.J. \& Gibson, R. Driving Performance and Digital Billboards. Center for Automotive Safety Research, 2007.

[19] Digital billboards and road safety. An analysis of current policy and research findings. Outdoor Media Association Inc.

[20] TERS: Guide to the Management of Roadside Advertising, Edition 1.0. TERS Product No. 80-500. Queensland Government, Department of Main Roads, 2002.

[21] Johnson, A. \& Cole, B. Investigations of Distraction by Irrelevant Information. Australian Road Research, 6(3), pp. 3-23, 1976.

[22] Farbry, J., Wochinger, K., Shafer, T., Owens, N. \& Nedzesky A., Research Review Of Potential Safety Effects of Electronic Billboards on Driver Attention and Distraction. Science Applications International Corporation, 8301 Greensboro Drive, USA.

[23] Martens M., Conceptual Guidelines for Roadside Distractions. Presentation to the Human Factors Workshop on Visual Clutter in the Road Environment. Washington, DC: Transportation Research Board 88th Annual Meeting, 2009.

[24] The South African National Roads Agency Limited And National Roads (SANRAL): Regulations on Advertising On or Visible From National Roads, 2000.

[25] Ustawa z dnia 21 marca 1985 r. O drogach publicznych. Dz. U. 1985 Nr 14 poz. 60. (pol.), (Law on public roads, dated March 21, 1985. Journal of Laws 1985 No. 14, item 60).

[26] Domke, K., Wandachowicz, K., Zalesinska, M., Mroczkowska, S. \& Skrzypczak, P. Ocena zagrozen wystepujacych w ruchu drogowym powodowana przez wielkopowierzchniowe reklamy $\mathrm{z}$ diodami swiecacymi. Raport $\mathrm{z}$ badan. (pol.), (Evaluation of risks in road traffic caused by large size LED billboards. Examination report) Poznan University of Technology, 2010.

[27] Cairney, P. \& Gunatillake, T. Roadside advertising signs - A review of the literature and recommendations for policy. ARRB Transport Research. Contract Report for RACV (Royal Automobile Club of Victoria), 2000.

[28] Wachtel, J. Safety Impacts of the Emerging Digital Display Technology for Outdoor Advertising Signs. Submitted Under NCHRP Project 20-7 (256), 2009.

[29] Inquiry into Driver Distraction, Road Safety Committee. Parliament of Victoria, Australia, 2006.

[30] Chan, E., Pradhan, A.K., Knodler, M.A., Pollatsek, A. \& Fisher, D.L. Evaluation on a driving simulator of the effect of drivers' eye behaviors from distractions inside and outside the vehicle. Human Factors, 2008.

[31] Amending chapter 28 of the city code of San Antonio, Texas, by adding provisions for digital signs. An ordinance: 2007-12-06-1247, NH/TM: 10/18/2007, http://www.sanantonio.gov/dsd/ pdf/B.pdf

[32] Zillmer, K., Oakdale ready for latest billboards - City passes dynamic sign ordinance. Oakdale Lake Elmo Review, 2008. 